Symunds, Paternoster Row, I808. Their titles, which I briefly give, will amply prove his professional position :-

(I) "Medical Admonitions to Families." 5th edition.

(2) "Observations on the Excessive Indulgence of Children."

(3) "The Village Friend and Physician." and edition.

(4) "The Way to Health."

(5) "The Chemical Pocket-Book."

(6) "Hints for the Improvement of Trusses."

(7) "The Hospital Pupil."

(8) "Observations on the Nature and Cure of Gout."

(9) "Remarks on Mr. Whitbread's Plan for the Education of the Poor."

(10) "Organic Remains of a Former World." Volume the

First.

In addition to his "Organic Remains," Parkinson produced "Elements of Oryctology, an Introduction to the Study of Fossil Organic Remains," which appeared in 1822. A third edition was published in 1840 .

Whatever may have been Parkinson's lack of interest in natural history when he acquired the museum, he certainly showed no deficiency in that respect when he produced his "Organic Remains of a Former World," one of the most valuable and interesting works of the kind that I know. For further information with regard to Parkinson, see the Introduction to Mantell's "Atlas of Fossil Remains," published by $H$. G. Bohn in 1850, in which Parkinson's splendid plates are reproduced. See also Allibone's "Dictionary of British and American Authors"; London, 1870.

Henbury, Bristol, October 29.

$$
\text { Sipencer George Perceval. }
$$

\section{On Chinese Beliefs about the North.}

From a review in NATURE for the 27th ult. (p. 522) I have been led to conclude that the "Theory of the Northern Origin of the Chinese" enjoys the confidence of scientific men. Should this conclusion really be correct, the theory will give strong support to the view which occurred to me while reading the review.

By Sze-má Kwáng, a Chinese Prime Minister of great classic knowledge (died 1086), the Rite of "Fuh" (i.e. bringing back), anciently observed before changing the clothes of deceased parents, is detailed as follows :- "Take a clean suit of clothes prepared for the corpse up to the ridge of the roof; then towards the north call three times 'Pray, return'; then fold up and bring down the suit to clothe the corpse; to detain the soul thus brought back, fasten the suit with silk (silken band); before the burial offer to it viands and utensils with as much reverence as is due to the parents alive" (I). In this ritual I notice three primitive beliefs unitedly preserved: firstly, that the soul of the deceased could return if called, the belief current among the Hos, the Bank's Islanders, and the Fijians of modern times (2); secondly, that one could detain the soul from departing by fastening a garment while addressing to the deceased, as is meant by an old Japanese usage on occasion of meeting the passing soul, i.e., ignis fatuns (3). In the third place, as is the case with the Kookies (4), this ritual indicates the primitive Chinese belief in the existence of their other world in the north.

The Early Chinese system of cosmogony, which is now fragmentally but uniformly preserved in the books of two antagonistic religions, viz. Confucianism and Taôism, has its God of the North named "Hiuen-Ming," i.e. "Entering Other World" (5).

Cháng Hwá, a Prime Minister of encyclopædic erudition (killed 300 A.D.), mentions in his work 2 Taôist belief in the other world as extensive as 200,000 lis square, situated underground in the north (6). Another Taôist Eschatology, written in the gth century A.D., relates that "the Emperor Yen-teh, who was created the "Grand Imperial Master of the North, governs all spiritual beings" (7). Most probably connected with these beliefs is a folk-tale of the " "South Dipper,' the ife-re pistrar, and the "North Dipper,' the death-registrar" (8), from which is derived a popular romance of Chau Yen's bribery to the latter star-god in order to have his destined longevity increased from nineteen years to ninety-nine (9).

The Yogâtchârya mystics of China define the north as "the point whereat all the works are doomed to finish," and hence "the point of entering Nirvana" (10). A dispute about whether Chinese Buddhism in this case is entirely free from the taint of Celestial gloss, I am not qualified to decide.
Now let us return to Confucian literature. Confucius's own opinion regarding the other world appears of quite agnostic character, as is implied in his answer to Tze-lu (who inquired about the state of death)- "While you do not know life, what can you know about death?" (II); as well as in his answer to Tze-kung (whose question was about whether the deceased had consciousness) - "If you die, you will know; even then it will not be too late to know "(I2). But it is in those ancient sages" tenets, which the great master preserved in his doctrine, that the early Chinese belief in the northern spirit.land had been so predominant, though tacitly implied, as to have caused an allreaching association of the North with everything related to Death. So, early they styled the rooms containing ancestral tablets the "North Temples" (13), and by the name "North Hill" the graveyard has al ways been understood.

According to the "Tang-kung" (a portion of the Book of Rites), Confucius was buried in the northern part of the capital of $\mathrm{Lu}$, and "the burial in the northern sides of towns was the persistent custom of the three 'classic dynasties,' i.e. Hia, Ying, and Chan" (14). Forcibly this statement reminds us of the Damaras, who place the corpse with the face towards the north, to remind them whence they originally came; and also of the Yncas, who, expecting to go to the east whence they came, turned the face of the corpse to the east; while the aboriginal Peruvians did not follow the same usage (I5). In fact, we find in Chinese records certain abnormal examples, which indicate the stocks distinct from original Chinese ; thus, two corpses of different sexes discovered from the mound of Prince Tsiikii, a Hiung-nú by descent, are said to have had their heads turned eastwards (I6).

Mr. Herbert Spencer, after reasoning from materials exten. sively collected, remarks: "Immigrant races have for their other-worlds the abodes of their fathers, to which they journey after death" (17); and unless they are an exception to this general rule, the Chinese, whose old customs and traditions have been shown to tend so much towards evincing their early belief in the northern spirit-land, must have originally entered their present domain from the North.

Also, in early Chinese speculations the north had been fixed on as the store and source of the originating principle "Yin" (or Negativity), and it has ever since been associated with everything of " negative" characters-e.g. reposing, obscuring, destroying, \&c. Thus, in the symbolism of "Wu-háng". (the Five Elements), water and winter are posted at the north (I8); of the nine divisions of the heavens the northern and the northwestern are named respectively "Dark Heaven "and "Dusky Heaven "(19); of the five mountains worshiped by emperors the northernmost one is called "Eternal Mountain" (Han Shan), because all beings are doomed to eternal repose in the north (20); and referring to the then admitted axiom- "the north is the realm of slaughters and assaults "-Confucius once reproved Tze-lu for playing on a stringed instrument in the "northern tones" (2I).

As there should be nothing other than Death that might combine in itself all conceivable characters of Negativity, it would seem quite reasonable to trace the origin of these associations of North and Negativity of Chinese speculations into the old custom of burying in grounds lying towards the north, which custom in its turn is easily traced to the early Chinese entrance from the north.

Bibliography.-(r) Kúmazawa, "Sồai Benron," Tokio, I89o, p. 4. (2) Spencer, "Principles of Sociology," 3rd edition, vol. i. \$ 83. (3) Terashima, "Wakan Sansai-dzue," I7 I3, tom. lviii. sub. "Hitotama." (4) Spencer, § I I2. (5) Pan Kú, Pehhú-tìng," 79 A.D. tom. ii. chap. i. (6) "Póh-wuh-chi," tom. i. chap. ii. (7) Twan Chiag-shih, "Yú-yáng Tsáh-tsú," tom. ii. (8) Sie Tsái-kang, "Wu.tsáh-tsú," circa I6IO, tom. i. (9) "Yen-i-Sán-kwóh-chì," Kin's edition I644, tom. xxxv. pp. 4-5. (Io) In-yû, "Mandara Shishô," I49r, tom. i. (II) "Confucian Analects," chap. xi. ; "Encyclopæedia Britannica," 9th edition, vol. vi. p. 265. (I2) Ying Chau, "Fung-siih. lùng," and cent. A.D., tom. ix. chap. ix. (I3) "Siun-tze," circa 255 B.C. xxviii. (14) "Peh-hú-ìng," tom. iv. chap. $x$. (15) Spencer, § I12. (I6) Li Shih, "Siih'Póh-wuh-chì," I $3^{\text {th }}$ cent. A.D. tom. viii. (I7) Spencer, \& II5. (18) "Peh-hú. tùng," tom. ii. chap. i. (I9) "Lii-shi Chùn-tsiú," circa 239 B.C. tom. xiii. chap. i. (20) "Fung-süh-tìng," tom. x. chap. i. (2r) Liu Hiáng, "Shwoh-yuen," Ist cent. B.C. tom. xix.

Kumagusu Minakata.

I 5 Blithfield Street, Kensington, W., October 16.

NO. I306, VOL. 517 